\title{
Sustainable Development and Protected Natural Areas: The Case of Tunkinsky National Park in Russia
}

\author{
By Sergey Kirillov ${ }^{1}$, Elena Vorobyevskaya ${ }^{1}$, Mikhail Slipenchuk ${ }^{1}$, Viktor \\ Zhuravlev $^{1}$
}

\begin{abstract}
The creation of rational nature management systems meets the needs of society and the necessary level of reproduction of natural resources and environmental protection. This is the main goal of the strategies for sustainable development of the regions. An integrated approach to assessing natural resource potential necessarily includes an economic assessment of the maximum possible number of environmental services. It forms the basis for territorial and sectoral planning. Protected natural areas have not only valuable biosphere resources, but also unique natural, historical and cultural opportunities for recreational activities. The territory of Tunkinsky National Park, located in the Republic of Buryatia in Russia, completely coincides with the borders of Tunkinsky administrative district of the Republic of Buryatia. Conflicts in the use of natural resources occur between the need to ensure the protection of nature and the development of economic activities. Using the example of Tunkinsky National Park, the role of a territory that is hardly affected by human economic activity, which provides ecologically important conditions for the life of society, is determined in monetary terms.
\end{abstract}

Keywords: Sustainable development, environmental management, ecosystem services, protected areas, national park, Russia

\section{Introduction}

The economic valuation of natural resources is a complex process aimed at identifying the value of ecosystems (Bobylev, Goryacheva, 2019). Such assessments are most often encountered when comparing the socio-economic efficiency of preserving the natural environment with industrial or other economic use of the territory (Kirillov et al., 2016).

An economic assessment is important for protected natural areas. This shows the importance of preserving the natural environment at sites that are hardly affected or unaffected by economic activity. Such territories have valuable biospheric resources (Bastian et al., 2015). It is important to preserve such resources for future generations. They have unique natural, historical and cultural opportunities for the development of recreation.

The benefits of ecosystems are known to everyone, but they are still not properly evaluated. These are direct resources of ecosystems, as well as opportunities for preserving biodiversity, landscape diversity, oxygen production, water filtration, prevention of adverse and dangerous natural phenomena, $\mathrm{CO}_{2}$ deposition, deposition of 
airborne industrial pollutants, provision of recreational services, and much more. Ecosystem services are invaluable to human life, but in order to preserve them, they need to be economically valued.

A fair economic assessment makes it possible to analyze biodiversity conservation projects, allocate limited material resources, prioritize investment activities, creating a justification for obtaining additional funds for the development of protected areas. Nature protection in protected areas requires substantiation of not only ecological, but also economic feasibility. Such assessments should become mandatory for the regions and be taken into account in their development strategies (Pakina, 2014).

The territory of Tunkinsky National Park, located in the Republic of Buryatia, was selected for the study. Since the formation of Tunkinsky National Park, the territory of which completely coincides with the borders of Tunkinsky district of the Republic of Buryatia, the nature management of the district has undergone significant changes. The use of natural resources is developing in accordance with the environmental legislation provided for economic activities within the national parks. This raises difficult questions related to the need, on the one hand, to ensure the protection of nature and, on the other hand, the need to develop economic activity. This is due to the fact that there are settlements on the territory of the district and here for a long time economic branches have been developing, which are life-supporting for the local population.

The research carried out in this paper can be considered as an interdisciplinary one, which reflects the main trend in the development of modern science. An attempt has been made on the basis of available data on the example of a specific territory to determine in monetary terms its role in providing environmentally important conditions for the life of a person and society. The aim of the study is to determine the economic value of protected natural areas using the example of Tunkinsky National Park.

\section{Study Area and Methods}

The study area has long been a place of traditional use of natural resources. People here hunted, fished, gathered wild plants, settled on the shores of lakes and rivers. In the 20th century, this area received intensive recreational development due to active tourism development, which was facilitated by good transport accessibility and the existing settlement infrastructure. Currently, the tourist activity of the national park is developing, the number of tourists is growing from year to year. There are interesting prospects for the development of the park related to nature conservation, recreational and traditional activities. However, there are certain development challenges and issues that require different approaches. The problem of determining the direction of the evolution of nature management in a specific territory in connection with the interaction of nature, economy and population has emerged. The object of research is the territory of Tunkinsky National Park (Figure 1). 


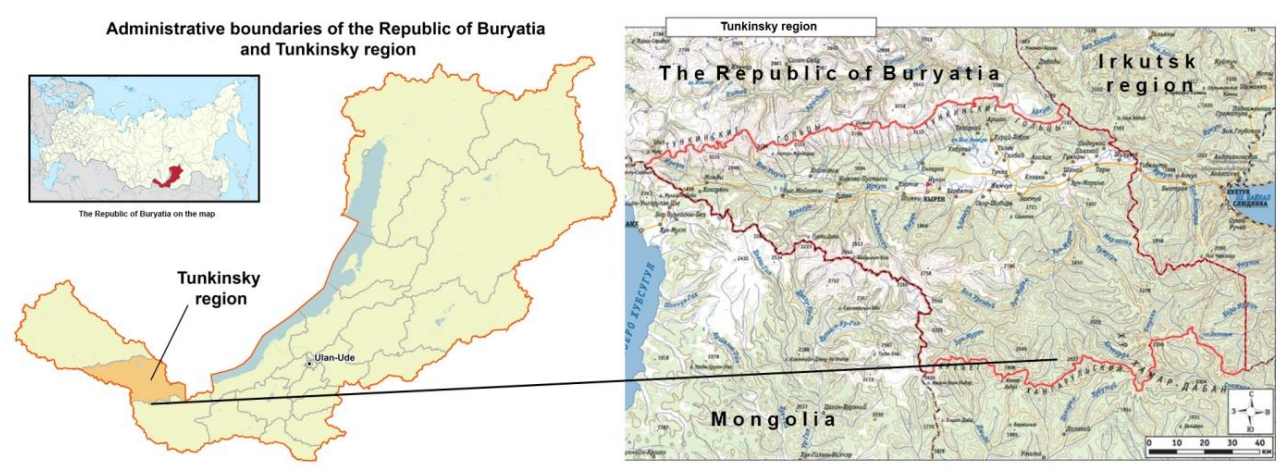

Figure 1. Location of Tunkinsky National Park

The methodological basis of the work is based on the scientific successes of the foreign (Constanza et al., 1997) and Russian schools of nature management study, historical geography, economic research in nature management. It should be noted research that was carried out under the auspices of international organizations, for example, Millennium ecosystem assessment and the economics of ecosystems and biodiversity. The applied aspects of measuring the economic value of environmental benefits are most deeply and thoroughly developed in relation to protected areas.

The territories of protected areas play a significant role in the formation of global markets for ecological services of ecosystems; the key task is their economic assessment and the introduction of indicators of sustainable development (Bobylev et al., 2018). At present, the situation with the recreational services provided by protected areas has been fairly well analyzed (Kirillov et al., 2014). The environment-forming functions of protected areas are not yet sufficiently evaluated. The experience of conducting an economic assessment of ecosystems is very interesting, including for protected areas or territories for which there is a choice of development options between nature conservation or economic activity (Tishkov, 2017).

The study was prepared based on materials from expeditions carried out by the Department of Environmental management of Moscow state university, as well as materials from the generalization and analysis of laws and legislative acts, literary and fund materials of the Faculty of geography of Moscow state university, the Buryat institute of nature management, the Institute of geography of the Siberian branch of the Russian academy of sciences, the Ministry of natural resources of the Republic of Buryatia, the administration of the village Arshan, local history museums, personal archival documents of local residents, etc. Also used are topographic maps, statements of the areas of the forest fund of the region; plans for projected forestry activities; taxation descriptions of forest fund plots; forest management plans; schemes for forestry, districts and recreation; materials on the issuance of licenses for hunting resource; information on hunting and fishing quotas; rules related to the harvesting of food forest resources and medicinal plants; survey data of hunters, local population, administration workers, forestry enterprises and other materials. The collection of the necessary data for the economic assessment was carried out during the expedition works in the summer of 
2018 and 2019.

The tasks require an integrated approach to their solution using systems analysis (Slipenchuk et al., 2016). Methods were used: comparative-descriptive, historicalgeographical, cartographic, mathematical, analytical, etc. The calculations carried out in this study were carried out according to the methods developed by the experts of the Environmental service of the World Bank. To carry out the total economic value, the following methods were used: market prices; transport and travel costs; analog method. Due to the imperfection of the methods, the calculations are approximate. Values obtained are in US dollars at the time of the assessment in 2020.

The method for determining the economic value of environmental benefits is considered in the context of the general economic value (GEV):

$\mathrm{GEV}=\mathrm{CN}+\mathrm{CU}$, where

$\mathrm{CN}$ - the cost of non-use;

$\mathrm{CU}$ - the cost of use.

Cost of use $(\mathrm{CU})$ is the sum of three terms:

$\mathrm{CU}=\mathrm{DCU}+\mathrm{ICU}+\mathrm{CDA}$, where

$\mathrm{DCU}$ - direct cost of use;

ICU - indirect cost of use;

$\mathrm{CDA}$ - the cost of the deferred alternative.

\section{Results}

The basis for economic calculations was information on the nature and use of natural resources in the study area (Batuev et al., 2015). A map was compiled, the analysis of which made it possible to provide primary information on the distribution of various types of natural lands throughout the study area. The total area of the territory is about 1,176,200 thousand hectares. The main types of land: forest 701,200 hectares, tundra 170,685 hectares, swamp 29,300 hectares, river and stream valleys 116,523 hectares, forest-steppe 54,673 hectares and steppe 103,819 hectares. Certain ecological services of the ecosystems of the study area have been identified (Table 1). Submitted list is far from complete, since the functions of ecosystems are a complex interconnected process.

Table 1. Ecosystem functions of Tunkinsky National Park

\begin{tabular}{|c|c|c|c|}
\hline No & $\begin{array}{l}\text { Environmental } \\
\text { services }\end{array}$ & $\begin{array}{c}\text { Significance } \\
\text { level }\end{array}$ & $\begin{array}{l}\text { Explanation } \\
\text { (main ecosystem functions) }\end{array}$ \\
\hline \multicolumn{4}{|c|}{ Direct services } \\
\hline 1 & $\begin{array}{l}\text { Use of natural raw materials: } \\
\text { hunting, fishing, wild plant } \\
\text { resources, pasture, } \\
\text { recreational resources }\end{array}$ & $\begin{array}{l}\text { Regional } \\
\text { and local }\end{array}$ & $\begin{array}{l}\text { Providing conditions for the development of agricultural, } \\
\text { resource-fishing, traditional, recreational use of natural } \\
\text { resources. Providing the need for food, medicinal raw } \\
\text { materials, etc. }\end{array}$ \\
\hline
\end{tabular}




\begin{tabular}{|c|c|c|c|}
\hline No & $\begin{array}{l}\text { Environmental } \\
\text { services }\end{array}$ & $\begin{array}{c}\text { Significance } \\
\text { level }\end{array}$ & $\begin{array}{l}\text { Explanation } \\
\text { (main ecosystem functions) }\end{array}$ \\
\hline 2 & $\begin{array}{l}\text { Services for regulating } \\
\text { climate, atmospheric } \\
\text { composition }\end{array}$ & $\begin{array}{l}\text { Global and } \\
\text { regional }\end{array}$ & $\begin{array}{l}\text { Maintaining a certain regime of air temperature, } \\
\text { precipitation, wind regime, etc. Regulation of the chemical } \\
\text { composition of the atmosphere, } \mathrm{CO}_{2} \text { balance, reduction of } \\
\text { greenhouse gases due to carbon sequestration by swamps } \\
\text { and forests. Cleaning the atmosphere from dust and } \\
\text { pollutants. Precipitation and absorption of pollutants by } \\
\text { biota and soils. }\end{array}$ \\
\hline 3 & Water supply & $\begin{array}{l}\text { Regional } \\
\text { and local }\end{array}$ & $\begin{array}{l}\text { Water storage, water supply for ecosystems, humans and } \\
\text { economic activities. }\end{array}$ \\
\hline 4 & Water purification services & Local & $\begin{array}{l}\text { Maintaining local characteristics of water quality. Water } \\
\text { filtration by swamps, soil cover. }\end{array}$ \\
\hline 5 & $\begin{array}{l}\text { Hydrological cycle } \\
\text { management services }\end{array}$ & $\begin{array}{c}\text { Global and } \\
\text { regional }\end{array}$ & $\begin{array}{l}\text { Biological water purification in natural reservoirs; using } \\
\text { forests to retain moisture in soils. }\end{array}$ \\
\hline 6 & $\begin{array}{l}\text { Service for the creation and } \\
\text { maintenance of a natural } \\
\text { habitat for biological, } \\
\text { including rare species }\end{array}$ & $\begin{array}{l}\text { Regional } \\
\text { and local }\end{array}$ & $\begin{array}{l}\text { Conservation functions, preservation of areas with little } \\
\text { changed nature, biodiversity, etc. }\end{array}$ \\
\hline 7 & $\begin{array}{l}\text { Preservation of ecosystems in } \\
\text { their integrity, regulation of } \\
\text { disturbances due to the } \\
\text { resistance of ecosystems to } \\
\text { adverse impacts }\end{array}$ & Local & $\begin{array}{l}\text { Reducing the likelihood of unfavorable and dangerous } \\
\text { phenomena due to the environment-forming functions of } \\
\text { ecosystems, protection from sudden gusts of wind, } \\
\text { landslides, mudflows, relief erosion, floods, droughts. }\end{array}$ \\
\hline 8 & $\begin{array}{l}\text { Creation and maintenance of } \\
\text { conditions for the } \\
\text { development of recreation, } \\
\text { landscape aesthetics }\end{array}$ & $\begin{array}{l}\text { Regional } \\
\text { and local }\end{array}$ & $\begin{array}{l}\text { The possibility of all-round health improvement and } \\
\text { recreation for people. }\end{array}$ \\
\hline 9 & Providing cultural resources & $\begin{array}{l}\text { Regional } \\
\text { and local }\end{array}$ & Spiritual, educational, scientific values of ecosystems. \\
\hline
\end{tabular}

Based on the concept of total economic value (Costanza et al., 2014), the component and aggregate values of the direct and indirect use of some ecosystem services were calculated. The following direct services were assessed: operational hunting and fishing resources, wild plant resources, recreational and pasture resources. Indirect services were also assessed: carbon sequestration by forests and swamps, water purification function of swamps. The total economic value of a number of ecosystem services in the area is estimated at almost US $\$ 41$ million per year (Table 2).

Table 2. Economic assessment of a number of ecosystem services of Tunkinsky National Park

\begin{tabular}{|l|c|}
\hline Ecosystem service & $\begin{array}{c}\text { Assessment in the territory of Tunkinsky } \\
\text { national park (in US dollars) }\end{array}$ \\
\hline Direct services & $64204 \$$ \\
\hline Hunting & $19784 \$$ \\
\hline Fishing & $5340108 \$$ \\
\hline Harvesting of wild plants & 10893682 \$ \\
\hline Recreational value & 2622187 \$ \\
\hline Pasture resources & $\mathbf{1 8 9 4 3 \mathbf { 4 6 8 } \$}$ \\
\hline Total & $\mathbf{1 6 , 1} \$$ \\
\hline Average cost of environmental services per hectare per year & $15089275 \$$ \\
\hline Indirect services &
\end{tabular}




\begin{tabular}{|l|c|}
\hline Ecosystem service & $\begin{array}{c}\text { Assessment in the territory of Tunkinsky } \\
\text { national park (in US dollars) }\end{array}$ \\
\hline Carbon sequestration by swamps & $401144 \$$ \\
\hline Water purification functions of swamps & $6519319 \$$ \\
\hline Total & $\mathbf{2 2 0 0 9 7 3 8 \$}$ \\
\hline Average cost of environmental services per hectare per year & $\mathbf{1 8 , 6} \$$ \\
\hline Full cost of environmental services & $40953206 \$$ \\
\hline Result & $\mathbf{3 4 , 7} \$$ \\
\hline Average cost of environmental services per hectare per year &
\end{tabular}

When calculating hunting, fishing and wild plant resources, the operational volume was taken into account as direct ecosystem services, and not the total biological one. The assessment of the biological stock of biota resources, for which the calculation was carried out, is associated with other biological resources. This can be seen as part of the park's conservation function to preserve biodiversity. Cutting of trees is prohibited on the territory of the park, which ensures the preservation of habitats of flora and fauna.

\section{Conclusion}

Ecosystem services assessments are of great practical importance, as they determine the economic value of conservation activities in comparison with other types of land use (Bukvareva et al., 2017). When assessing protected areas of certain categories, not only direct resource services are subject to accounting: hunting and fishing, wild plants, pasture, timber and deadwood harvesting, etc., but also indirect ones. Although the economic significance of resource services is obvious, its assessment is often difficult due to the lack of statistical data and, in some cases, significant interannual variability. The assessment of a number of indirect services can be carried out according to existing methodologies that have been successfully tested in different countries and in different regions, but most of these services do not yet have clear methods for assessing their functions.

The analysis made it possible to identify the ecological functions of the natural-territorial complexes of Tunkinsky National Park. Only those functions that are amenable to economic assessments at the present stage are taken into account. The following ecosystem services were carried out: a) direct biological resources (for a number of animals, fish, wild plants); recreational resources; pasture resources; b) indirect resources such as carbon sequestration by forests and marshes, filtration capacity of marshes.

The results of the economic assessment prove that the cost of an incomplete list of ecological services of the park's ecosystems is high. Their primary value was \$ 41 million per year, including an estimate of direct services of about $\$ 18$ million, indirect services of about $\$ 22$ million. The resulting value of the direct and indirect use of the ecosystems of the national park is about $1.2 \%$ of the gross regional product of the Republic of Buryatia, while the national park occupies 3\% of the area in the Republic of Buryatia and $2 \%$ of the population of the Republic of Buryatia. Conducting such assessments helps to show not only the ecological, but also the economic value of ecosystems that are hardly affected by anthropogenic activity.

\section{Acknowledgments}


This research was performed according to the Development program of the Interdisciplinary Scientific and Educational School of Lomonosov Moscow State University «Future Planet and Global Environmental Change» and within the framework of the state assignment "Sustainable development of territorial nature management systems".

\section{References}

Bastian, O., Grunewald, K. \& Khoroshev, A. V. (2015). The significance of geosystem and landscape concepts for the assessment of ecosystem services: exemplified in a case study in Russia. Landscape Ecology, 30 (7), 1145-1164. doi: 10.1007/s10980-015-0200-x

Batuev, A. R., Beshentsev, A. N., Bogdanov, V. N., Dorjgotov, D., Korytny, L. M. \& Plyusnin, V. M. (2015). Ecological atlas of the Baikal basin: cartographic innovation. Geography and Natural Resources, 36 (1), 1-12. doi: 10.1134/S1875372815010011

Bobylev, S. \& Goryacheva, A. (2019) Identification and Assessment of Ecosystem Services: The International Context. International Organisations Research Journal, 14 (1), 225-236. doi: 10.17323/1996-7845-2019-01-01

Bobylev, S. N., Chereshnya, O. Y., Kulmala, M., Lappalainen, H. K., Petäjä, T., Solov'eva, S. V., Tikunov, V. S. \& Tynkkynen, V. (2018). Indicators for digitalization of sustainable development goals in PEEX program. Geography, Environment, Sustainability, 11 (1), 145-156. doi: 10.24057/2071-9388-2018-11$1-145-156$

Bukvareva, E., Zamolodchikov, D., Kraev, G., Grunewald, K. \& Narykov, A. (2017). Supplied, demanded and consumed ecosystem services: Prospects for national assessment in Russia. Ecological Indicators, 78, 351-360. doi: 10.1016/j.ecolind.2017.03.034

Constanza, R., d'Arge, R., de Groot, R. et al. (1997). The value of the world's ecosystem services and natural capital. Nature, 387, 253-260.

Costanza, R., De Groot, R., Sutton, P. et al. (2014). Changes in the global value of ecosystem services. Global Environmental Change, 26, 152-158. doi: 10.1016/j.gloenvcha.2014.04.002

Kirillov, S., Sedova, N., Vorobyevskaya, E. \& Zengina, T., (2014). Problems and prospects for tourism development in the Baikal Region, Russia. 14th GeoConference on ecology, economics, education and legislation, 2, 531-538. doi: 10.5593/SGEM2014/B52/S20.070

Kirillov, S., Slipenchuk, M. \& Zengina, T. (2016). Management of the sustainable development of the Baikal natural territory in Russia. International Journal of Innovation and Sustainable Development, 10 (1), 57-68. doi: 10.1504/IJISD.2016.073418

Pakina, A. A. (2014). Green Economy's Prospects in Russia: Case of Baikal Area. Journal of Sustainable Development of Energy, Water and Environment Systems, 2 (2), 139-151. doi: 10.13044/j.sdewes.2014.02.0013

Slipenchuk, M., Vorobyevskaya, E., Kirillov, S. \& Telelekova, A. (2016). Multifaceted approach to natural resource management: ethnology, geography, culture. Journal of the Geographical Institute "Jovan Cvijic" SASA, 66 (3), 449-455. doi: 10.2298/IJGI1603449S

Tishkov, A. A. (2017). Development of Russia's Network of Nature Reserves and Academic Science of the 20th Century. Herald of the Russian Academy of Sciences, 87 (4), 385-395. doi: 10.1134/S1019331617040128 